\title{
In vitro Response of Human Pathological Hematopoietic Cells to Cladribine*
}

\author{
Lidia MAZUR, Małgorzata OPYDO-ChANEK, Marta STOJAK, Barbara JANOTA, Kamil BlichARSKI, \\ Katarzyna WOJCIESZEK, Urszula KŁAPUT and Piotr BOROwICZ
}

Accepted May 15, 2013

\begin{abstract}
Mazur L., Opydo-Chanek M., Stojak M., Janota B., Blicharski K., Wojcieszek K., KŁAPUT U., BOROWICZ P. 2013. In vitro response of human pathological cells to cladribine. Folia Biologica (Kraków) 61: 143-148.

The influence of cladribine (2-chloro-2'-deoxyadenosine, CdA) on in vitro response of human acute lymphoblastic leukemia MOLT-4 cells, human histiocytic lymphoma U-937 cells, and human promyelocytic leukemia HL-60 cells, was determined using the MTT spectrophotometric and Beckman Coulter methods. Cell viability, cell volume and count were compared $24 \mathrm{~h}$ and $48 \mathrm{~h}$ after cladribine application at four concentrations $-50 \mathrm{nM}$, $100 \mathrm{nM}, 250 \mathrm{nM}$, and $500 \mathrm{nM}$. Different patterns of temporary changes in the viability, volume and count of pathological hematopoietic cells exposed to the action of CdA were found. The effects of CdA on MOLT-4, U-937, and HL-60 cells were dependent on the agent tested and its concentration, the time intervals after agent application, and the cell line used The various in vitro cytotoxic activities of $\mathrm{CdA}$ against the three human pathological hematopoietic cell lines were shown.
\end{abstract}

Key words: Human pathological hematopoietic cells, cladribine, in vitro cell response, cell viability, cell volume and count.

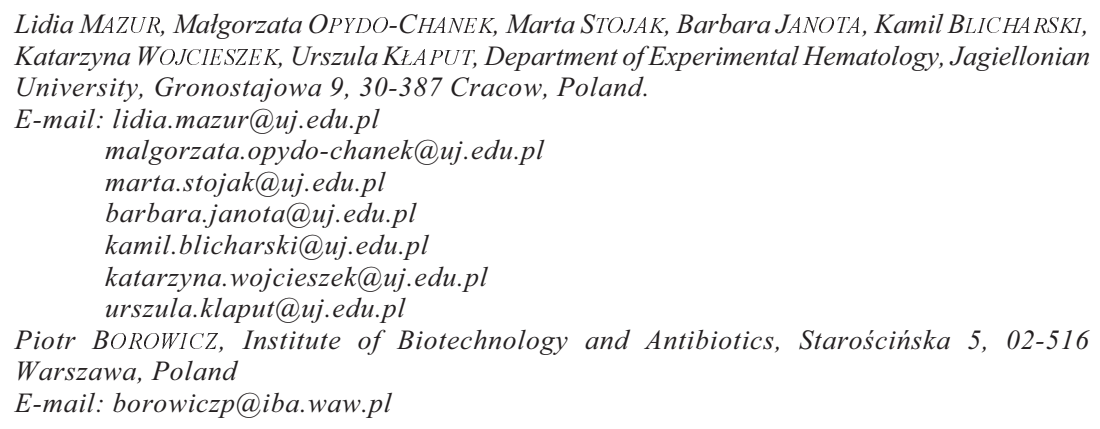

The purine nucleoside analog - cladribine (2-chloro-2'-deoxyadenosine, CdA) represents a novel cytotoxic chemotherapeutic agent. Cladribine has established clinical activity in hematological malignancies (DELANNOY 1996; ROBAK 2003; PARKER et al. 2004; GREYZ \& SAVEN 2004; ROBAK et al. 2005, 2006a, 2006b, 2006c). Nevertheless, some aspects of the action of cladribine are as yet unclear. Available information on biological properties of $\mathrm{CdA}$ and its cytotoxic activity against different pathological hematopoietic cells is still scarce (GUCHELAAR et al. 1994; LOTFI et al. 1999; MANSSON et al. 1999; STACHNIK et al.
2005). In any case, to our knowledge, changes occurring in the cell volume following cladribine application have not yet been observed.

The present study was undertaken in order to evaluate and compare the in vitro response of three human pathological hematopoietic cell lines to the action of cladribine. Temporary changes in the viability, volume, and count of human acute lymphoblastic leukemia MOLT-4 cells, human histiocytic lymphoma U-937 cells, and human promyelocytic leukemia HL-60 cells subjected to the action of CdA, were analyzed.

\footnotetext{
* Supported by Research Projects K/ZDS/001959 and K/ZDS/002597.
} 


\section{Material and Methods}

\section{Cells}

Human acute lymphoblastic leukemia MOLT-4 cells (ECACC, European Collection of Cell Cultures, UK), human histiocytic lymphoma U-937 cells and human promyelocytic leukemia HL-60 cells (American Type Culture Collection, USA), were maintained in RPMI 1640 medium (Gibco BRL Life Technologies) supplemented with $10 \%$ fetal calf serum (GIBCO BRL Life Technologies), $2 \mathrm{mML}$-glutamine (Sigma Aldrich), and antibiotic antimycotic solution (AAS, Sigma Aldrich). AAS contained 20 units of penicillin, $20 \mathrm{mg}$ streptomycin and $0.05 \mathrm{mg}$ amphotericin B. Every third day, the cells were passaged. The cells grew at $37^{\circ} \mathrm{C}$ in an atmosphere of $5 \% \mathrm{CO}_{2}$ in air (HERAcell incubator, KendroLab).

\section{Cladribine concentrations and cell treatment}

Cladribine (Biodribin, Cladribinum, CdA, BIOTON, Institute o Biotechnology and Antibiotics, Warsaw) was used. Cladribine was diluted in aqua pro injectione (Polpharma). All solutions were freshly prepared directly before treatment of cells. After a dilution of the cell suspension to a density of $15 \times 10^{4}$ cells $/ \mathrm{ml}$ medium, MOLT-4, U-937, and
HL-60 cells were subjected to antimetabolite agent exposure. The cells were exposed to the action of cladribine at four concentrations of $50 \mathrm{nM}$, $100 \mathrm{nM}, 250 \mathrm{nM}$ and $500 \mathrm{nM}$. The control material consisted of untreated cells.

\section{MTT assay and Beckman Coulter method}

Temporary changes occurring in MOLT-4, U-937, and HL-60 cells were observed $24 \mathrm{~h}$ and $48 \mathrm{~h}$ after cell exposure to cladribine. At these two time intervals, the cell viability, and the cell volume and count, were analyzed. The research was conducted using the spectrophotometric MTT (3-[4,5-dimethylthiazol-2-yl]-2,5-diphenyl tetrazolium bromide) assay and the electronic Beckman Coulter method. In viable, metabolically active cells, the tetrazolium ring of MTT is cleaved, yielding formazan crystals. Changes in the metabolic activity of cell populations result in a concomitant change in the amount of formazan formed. The Beckman Coulter method of cell sizing and counting is based on the detection of an electrical pulse which results from the passage of each cell through an aperture. The amplitude of the produced electrical pulse depends on the cell volume. The number of pulses indicates the cell count.

Table 1

The effects of cladribine on MOLT-4, U-937, and HL-60 cells. The data are presented as mean values \pm standard deviation. Values not significantly different at $\mathrm{P}<0.05$ according to Duncan's test: ${ }^{1,2,3,4,5}$ between the particular experimental groups; ${ }^{24,48}$ between the time points

\begin{tabular}{|c|c|c|c|c|c|c|c|c|}
\hline \multicolumn{2}{|c|}{$\begin{array}{l}\text { Experimen- } \\
\text { tal group }\end{array}$} & \multirow{4}{*}{$\begin{array}{l}\text { Cell } \\
\text { line }\end{array}$} & \multicolumn{6}{|c|}{ Time intervals after cell exposure to $\mathrm{CdA}$} \\
\hline \multirow{3}{*}{ No. } & \multirow{3}{*}{$\begin{array}{c}\mathrm{CdA} \\
\text { concentra- } \\
\text { tion }\end{array}$} & & $24 \mathrm{~h}$ & $48 \mathrm{~h}$ & $24 \mathrm{~h}$ & $48 \mathrm{~h}$ & $24 \mathrm{~h}$ & $48 \mathrm{~h}$ \\
\hline & & & \multicolumn{2}{|c|}{$\begin{array}{l}\text { Optical density of formazan } \\
\text { solution }\left(\times 10^{-3}\right)\end{array}$} & \multicolumn{2}{|c|}{ Mean cell volume (fL) } & \multicolumn{2}{|c|}{ Cell count $\left(\mathrm{x} 10^{3}\right)$} \\
\hline & & & Mean \pm SD & Mean \pm SD & Mean \pm SD & Mean \pm SD & Mean \pm SD & Mean \pm SD \\
\hline 1 & $50 \mathrm{nM}$ & $\begin{array}{c}\text { MOLT-4 } \\
\text { U-937 } \\
\text { HL-60 }\end{array}$ & $\begin{array}{c}57 \pm 2 \\
226 \pm 12^{2} \\
290 \pm 5^{2,5}\end{array}$ & $\begin{array}{c}93 \pm 3 \\
472 \pm 33 \\
448 \pm 13\end{array}$ & $\begin{array}{l}1503 \pm 87 \\
3112 \pm 105^{48 h} \\
3626 \pm 189^{2}\end{array}$ & $\begin{array}{l}1623 \pm 53 \\
3134 \pm 183^{24 h} \\
4636 \pm 63^{2}\end{array}$ & $\begin{array}{l}198.14 \pm 7.90 \\
216.07 \pm 8.10 \\
200.54 \pm 7.73^{2}\end{array}$ & $\begin{array}{l}313.41 \pm 27.86 \\
401.41 \pm 19.04 \\
245.21 \pm 10.18\end{array}$ \\
\hline 2 & $100 \mathrm{nM}$ & $\begin{array}{c}\text { MOLT-4 } \\
\text { U-937 } \\
\text { HL-60 }\end{array}$ & $\begin{aligned} 51 & \pm 2^{5} \\
221 & \pm 8^{1} \\
277 & \pm 8^{1,3,4,5}\end{aligned}$ & $\begin{aligned} 72 & \pm 2 \\
389 & \pm 15 \\
385 & \pm 4\end{aligned}$ & $\begin{array}{l}1644 \pm 24^{3} \\
3531 \pm 171^{48 h} \\
3705 \pm 111^{1}\end{array}$ & $\begin{array}{l}1327 \pm 180 \\
3609 \pm 78^{24 h} \\
4541 \pm 167^{1,3}\end{array}$ & \begin{tabular}{|c|}
$179.84 \pm 5.63^{48 h}$ \\
$188.92 \pm 4.71$ \\
$184.62 \pm 4.61^{1,3}$
\end{tabular} & $\begin{array}{l}173.76 \pm 13.55^{24} \\
300.40 \pm 12.04 \\
168.74 \pm 7.18\end{array}$ \\
\hline 3 & $250 \mathrm{nM}$ & $\begin{array}{c}\text { MOLT-4 } \\
\text { U-937 } \\
\text { HL-60 }\end{array}$ & $\begin{array}{c}37 \pm 2 \\
212 \pm 6^{4,5} \\
265 \pm 12^{2,4} \\
\end{array}$ & $\begin{array}{c}42 \pm 1 \\
323 \pm 11 \\
331 \pm 7^{4} \\
\end{array}$ & $\begin{array}{l}1635 \pm 119^{2} \\
3727 \pm 183 \\
3938 \pm 182^{4}\end{array}$ & $\begin{array}{c}824 \pm 66 \\
4232 \pm 125^{4} \\
4484 \pm 96^{2} \\
\end{array}$ & \begin{tabular}{|c|}
$157.66 \pm 4.30^{4}$ \\
$165.72 \pm 5.79^{48 h}$ \\
$166.58 \pm 6.79^{2.4}$ \\
\end{tabular} & $\begin{array}{l}129.91 \pm 5.02 \\
157.53 \pm 8.21^{24 h} \\
134.07 \pm 5.24^{4}\end{array}$ \\
\hline 4 & $500 \mathrm{nM}$ & $\begin{array}{c}\text { MOLT-4 } \\
\text { U-937 } \\
\text { HL-60 }\end{array}$ & $\begin{aligned} 31 & \pm 3 \\
211 & \pm 1^{3,5} \\
263 & \pm 12^{2,3}\end{aligned}$ & $\begin{aligned} 15 & \pm 2 \\
286 & \pm 12 \\
328 & \pm 24^{3}\end{aligned}$ & $\begin{array}{l}1425 \pm 97 \\
3865 \pm 153 \\
4043 \pm 152^{3}\end{array}$ & $\begin{aligned} & 751 \pm 45 \\
& 4327 \pm 76^{3} \\
& 4350 \pm 121 \\
&\end{aligned}$ & $\begin{array}{l}134.05 \pm 9.00^{3} \\
149.22 \pm 3.13 \\
160.95 \pm 8.04^{3}\end{array}$ & $\begin{array}{l}109.54 \pm 9.28 \\
120.26 \pm 7.11 \\
118.96 \pm 7.00^{3}\end{array}$ \\
\hline 5 & Control & $\begin{array}{c}\text { MOLT-4 } \\
\text { U-937 } \\
\text { HL-60 }\end{array}$ & $\begin{array}{c}51 \pm 8^{2} \\
205 \pm 8^{3,4} \\
281 \pm 15^{1,2}\end{array}$ & $\begin{array}{l}132 \pm 7 \\
493 \pm 15 \\
500 \pm 51\end{array}$ & $\begin{array}{l}1105 \pm 47^{48 h} \\
2149 \pm 29^{48 h} \\
2195 \pm 33^{48 h}\end{array}$ & $\begin{array}{l}1125 \pm 17^{24 h} \\
2223 \pm 39^{24 h} \\
2236 \pm 63^{24 h}\end{array}$ & $\begin{array}{l}296.05 \pm 8.53^{1,2} \\
343.71 \pm 22.36 \\
366.34 \pm 28.78\end{array}$ & $\begin{array}{l}625.42 \pm 14.92 \\
793.62 \pm 16.11 \\
767.13 \pm 25.61\end{array}$ \\
\hline
\end{tabular}




\section{Cell viability assay}

MTT (Sigma-Aldrich) was dissolved in RPMI 1640 medium, at a concentration of $5 \mathrm{mg} / \mathrm{ml}$, and filtered through a $0.2 \mu \mathrm{m}$ filter. $100 \mu \mathrm{l}$ of the yellow MTT solution was added to each well of a 24-well plate, containing $1 \mathrm{ml}$ of the cell suspension. The cells were then incubated at $37^{\circ} \mathrm{C}$ with $5 \% \mathrm{CO}_{2}$. A blank solution was prepared according to the above procedure using complete medium without cells. After the three-hour incubation period, the resulting formazan crystals were dissolved with $1 \mathrm{ml}$ of acidified isopropanol $(0.05 \mathrm{~N} \mathrm{HCl}$ in absolute isopropanol), and absorbance of the obtained solution was measured at a wavelength of $570 \mathrm{~nm}$ using a Pharmacia Ultrospec III spectrophotometer (Pharmacia). The extent of MTT conversion in cells was also expressed as a percentage value of the control.

\section{Measurement of cell volume and count}

Samples of the acute leukemia cell suspension were taken from wells of a 24-well plate and immediately diluted in ISOTON II (Beckman Coulter filtered electrolyte solution based on $0.9 \%$ saline). $500 \mu \mathrm{l}$ of the cell suspension was added to $4.5 \mathrm{ml}$ of ISOTON II. After the dilution of the leukemia cell suspension, individual cells were measured using a Z2 Coulter counter (Beckman Coulter, USA). The volume and count distribution of leukemia cells was obtained using a counter equipped with a $100 \mu \mathrm{m}$ diameter orifice. The flow rate was $500 \mu \mathrm{l} / 12.5 \mathrm{sec}$. The instrument was calibrated using $10 \mu \mathrm{m}$ diameter latex beads (Beckman Coulter CC size standard). The mean cell volume and the cell count were determined using Z2 AccuComp software (Beckman Coulter, USA).

\section{Statistical evaluation}

Statistical significance of differences in the amount of formazan formed and the cell volume and count were evaluated by an analysis of variance and the Duncan's new multiple range test. A difference with $\mathrm{P}<0.05$ was considered statistically significant. The results were confirmed by three independent experiments carried out in triplicate.

\section{Results and Discussion}

In the present study the influence of cladribine on MOLT-4, U-937, and HL-60 cells was determined. Temporary changes in the optical density of formazan solution which reflects cell viability (Table 1, Fig. 1A) and in the volume (Table 1,
Fig. 1B and Fig. 2) and count (Table 1, Fig.1C) of the human pathological hematopoietic cells, were evaluated at $24 \mathrm{~h}$ and $48 \mathrm{~h}$ after CdA application. The results demonstrated that the viability of MOLT-4, U-937, and HL-60 cells was reduced at $48 \mathrm{~h}$ after CdA application. Fluctuations in the viability values were observed at $24 \mathrm{~h}$ after cell exposure to the action of this purine nucleoside analog. Among the human cell lines tested, the lowest viability values were found in MOLT-4 cells. The mean cell volume distinctly increased when CdA was applied, with the exception of decreased values found only in MOLT-4 cells when this agent was given at higher concentrations $250 \mathrm{nM}$ and $500 \mathrm{nM}$. Cladribine application caused a count reduction of MOLT-4, U-937, and HL-60 cells. The various patterns of temporary alterations in the cell viability, volume and count depended on the concentration of $\mathrm{CdA}$ given, the time intervals after its application, and the cell line used.

Taking into account our results concerning cell viability, volume and count, it can be stated that the mode of cladribine action on the three pathological hematopoietic cell lines varied distinctly. It is suggested that MOLT-4, U-937, and HL-60 cells underwent different types of programmed death. It is assumed that an increase of the mean cell volume may indicate that the cells undergo mitotic catastrophe or programmed necrosis, and a decrease of the mean cell volume can be the result of apoptotic processes occurring in the cell population. It should be emphasized that the exact mechanisms of the action of cladribine on human acute lymphoblastic leukemia MOLT-4 cells, human histiocytic lymphoma U-937 cells, and human promyelocytic leukemia HL-60 cells have not yet been determined and compared.

The mechanisms of action of CdA on different types of cells are not fully known (GUCHELAAR et al., 1994; WILSON et al. 1998; LOTFI et al., 1999; MANSSON et al., 1999; NIITSU et al., 2000; GALMARINI et al. 2001). It is accepted that the uptake of CdA into the cell can significantly modulate the intracellular bioavailability of this agent. The biological activity of CdA depends on the preferential accumulation of cladribine phosphates in the cell. The nucleoside of this purine analogue is transported into cells and sequentially phosphorylated to its triphosphate derivative by deoxycytidine kinase, adenylate kinase and then nucleoside diphosphate kinase $: \mathrm{CdA} \rightarrow \mathrm{CdA}-\mathrm{MP}$ $\rightarrow$ CdA-DP $\rightarrow$ CdA-TP. Cladribine accumulates in the cells as chlorodeoxyadenosine triphosphate (HUBER-RUANO et al. 2009). The mechanisms of cladribine activity are based on inhibition of enzymes involved in DNA, RNA, and protein synthesis. Cytotoxicity of $\mathrm{CdA}$ is associated with 
A

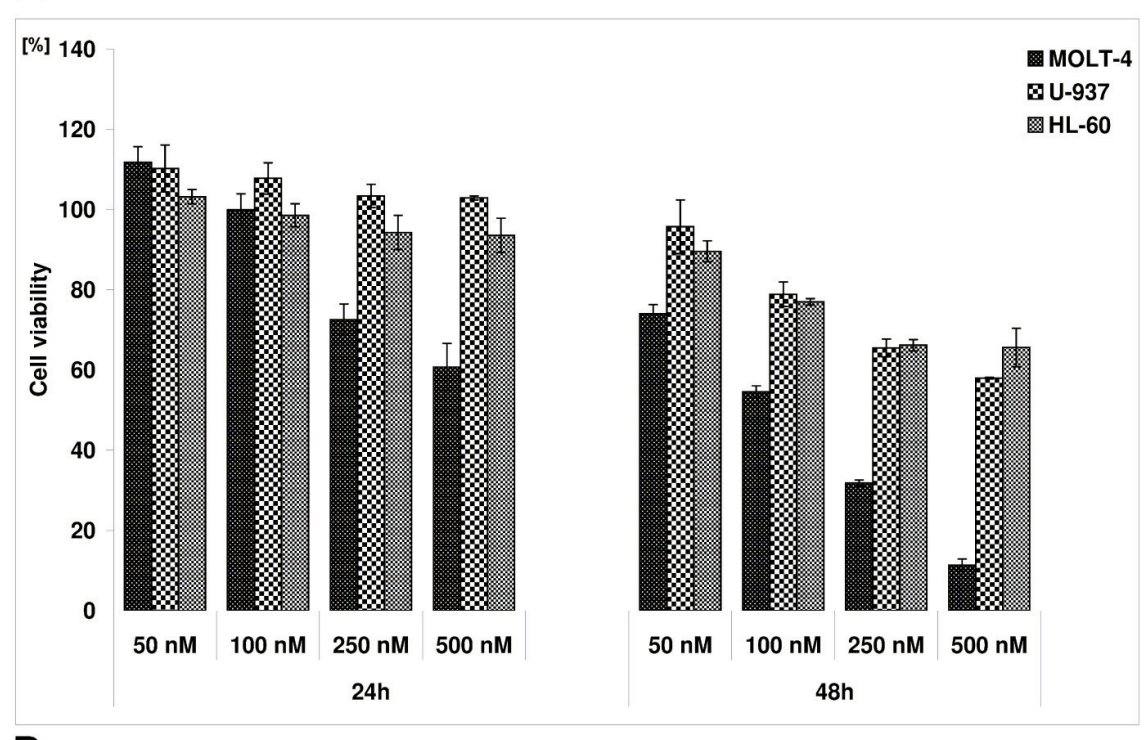

B

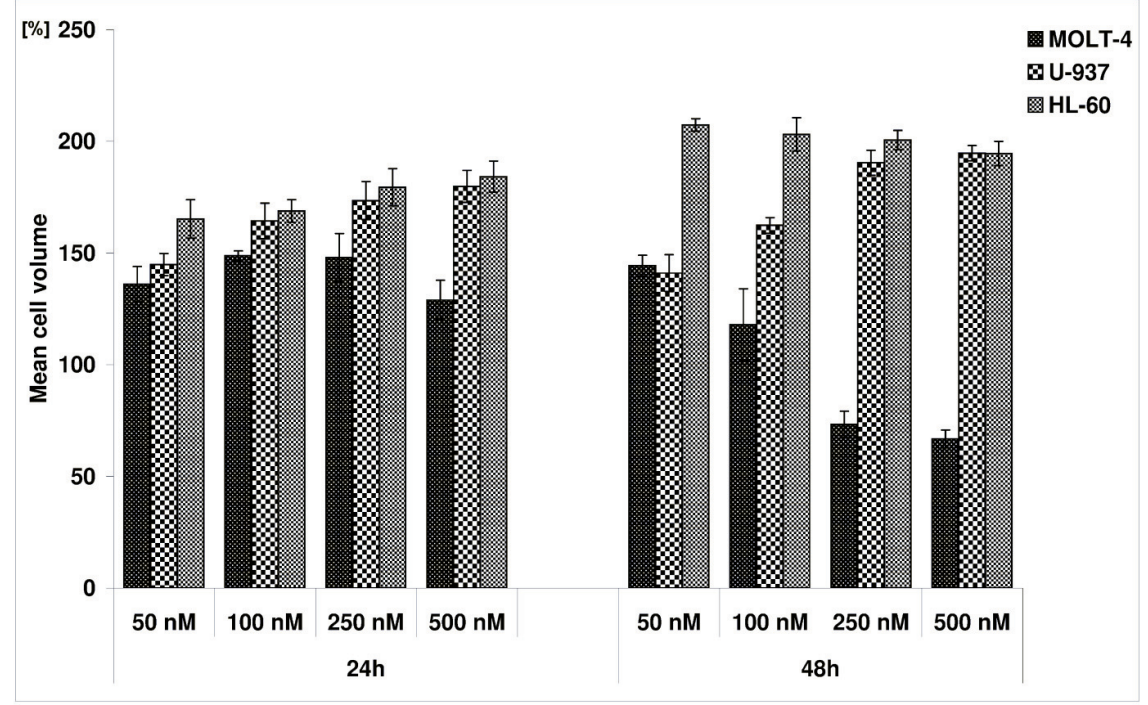

C

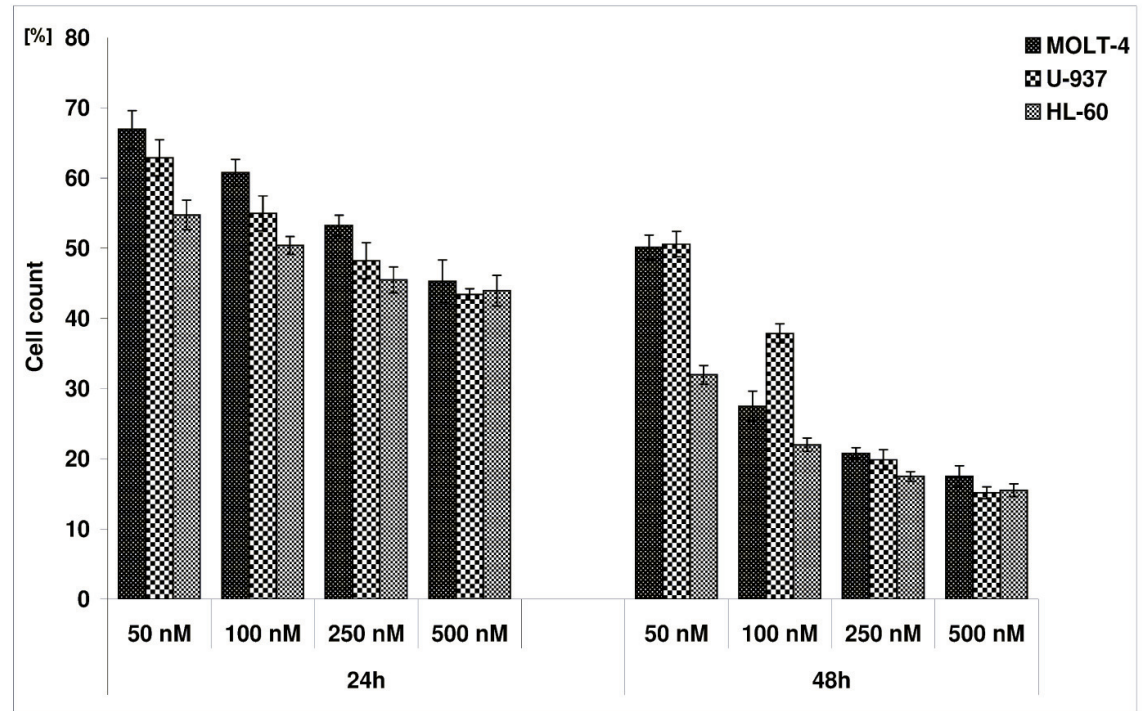

Fig. 1. The viability (A), mean volume (B), and count (C) determined in MOLT-4, U-937, and HL-60 cells after exposure to cladribine, and expressed as percentage values of the controls. 

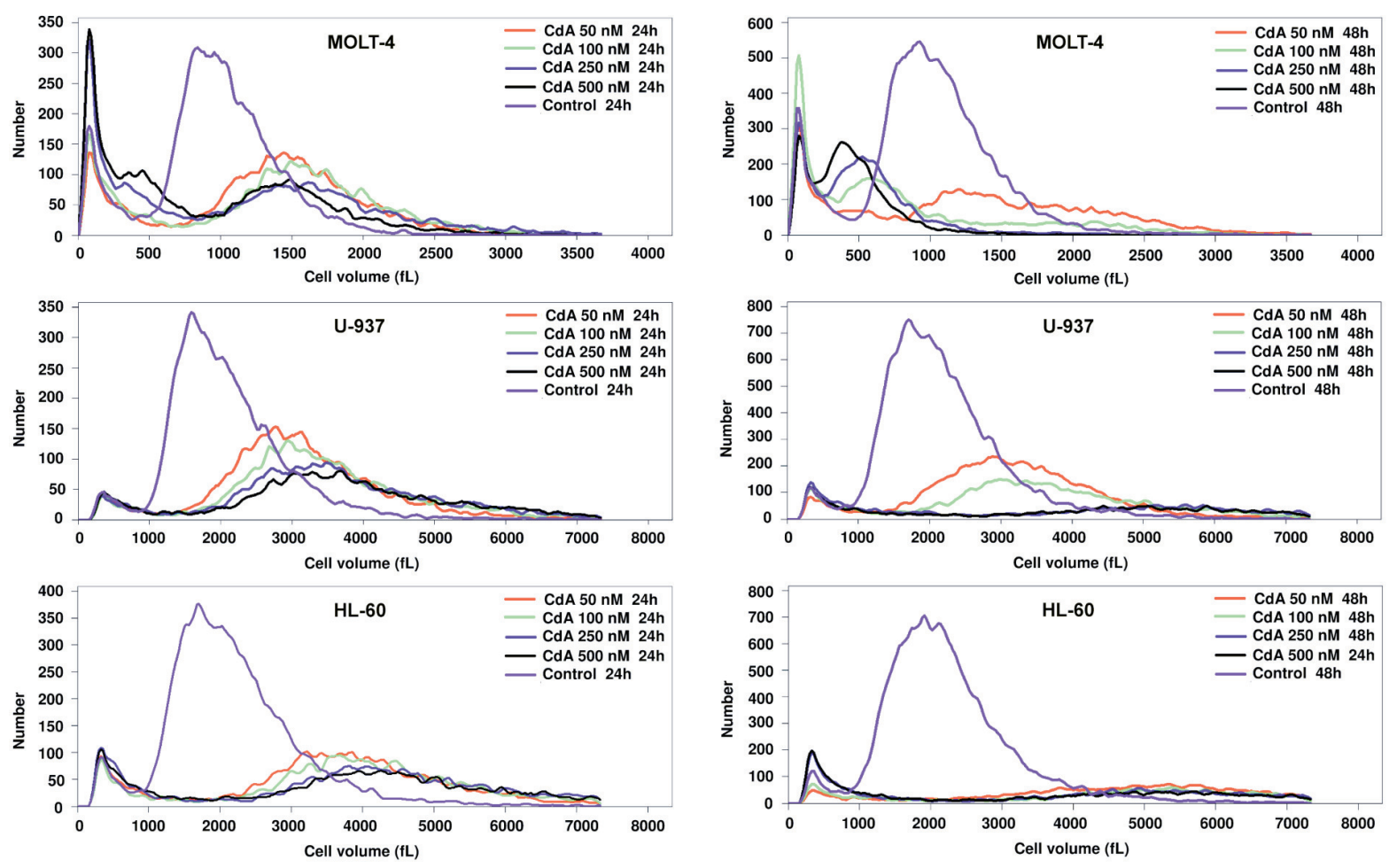

Fig. 2. The mean volume distribution curves of MOLT-4, U-937, and HL-60 cells recorded 24h and 48h after exposure to cladribine $(\mathrm{CdA})$ at four concentrations of $50 \mathrm{nM}, 100 \mathrm{nM}, 250 \mathrm{nM}$, and $500 \mathrm{nM}$. The peaks on the left represent cellular debris which were excluded from the analysis of cell volume.

events critical to cell entry into S phase (BEUTLER 1992; ROBAK et al. 2006a, 2006b).

Cladribine has cytotoxic effects on resting and proliferating cells. The cytotoxicity of $\mathrm{CdA}$ in the proliferating cells is mainly due to either suppression of DNA synthesis via inhibition of DNA polymerases, or incorporation into DNA, or inhibition of DNA repair and accumulation of DNA breaks. CdA inhibits also ribonucleotide reductase activity leading to imbalance in deoxynucleotide triphosphates pool, and via endonuclease activation leads to DNA strand breaks. The cytotoxic action of CdA may also originate from the inhibition of deoxyadenosine deamination and phosphorylation, and subsequent inactivation of 5 -adenosylhomocysteine hydrolase as a natural consequence of adenosine accumulation. In quiescent cells, CdA interferes with proper repair of DNA and leads to a total disruption of cellular metabolism via accumulation of breaks in the DNA strand. The formation of DNA strand breaks, inhibition of DNA synthesis and repair, nicotinamide adenine dinucleotide (NAD) and ATP depletion, can consequently lead to cell death (WILSON et al. 1998; GENINI et al. 2000; MARZO et al. 2001; FABIANOWSKA-MAJEWSKA \& KRAWCZYK 2005; EWALD et al. 2008).
To summarize the results obtained, the cytotoxic effects of cladribine surely resulted from its various action on MOLT-4, U-937 and HL-60 cells and the different status of the cells. The in vitro response of the human pathological hematopoietic cells to cladribine was found. A better understanding of the mode of cladribine action and precise mechanisms responsible for the response of different cell types to this purine nucleoside analog is of key importance in chemotherapy.

\section{Reference}

BEUTLER E. 1992. Cladribine (2-chlorodeoxyadenosine). Lancet 340: 925-926.

DELANNOY A. 1996. 2-Chloro-2'-deoxyadenosine: clinical applications in hematology. Blood Rev. 10: 148-166.

Ewald B., SAmpath D., Plunkett W. 2008. Nucleoside analogs: molecular mechanisms signaling cell death (Review). Oncogene 27: 6522-6537.

FABIANOWSKA-MAJEWSKA K., KRAWCZYK B. 2005. Mechanism of action of nucleoside analogues used in blood cancer therapy. Acta Haematol. Pol. 36: 55-72.

GALMARINI C.M., MACKEY J.R., DUMONTET C. 2001. Nucleoside analogues: mechanisms of drug resistance and reversal strategies. Leukemia 15: 875-890.

Genini D., ADACHI S., ChaO Q., Rose D.W., CARRERA C.J., COTTAM H.B., CARSON D.A., LEONI L.M. 2000. Deoxyadenosine analogs induce programmed cell death in chronic 
lymphocytic leukemia cells by damaging the DNA and by directly affecting the mitochondria. Blood 96: 3537-3543.

GREYZ N., SAVEN A. 2004. Cladribine: from the bench to the bedside - focus on hairy cell leukemia. Expert Rev. Anticancer Ther. 4: 745-757.

GuChelaAR H.J., Richel D.J., SCHAAFSMA M.R. 1994. Clinical and toxicological aspects of the antineoplastic drug cladribine: a review. Ann. Hematol. 69: 223-230.

Huber-RuAnO I., PASTOR-ANGLADA M. 2009. Transport of nucleoside analogs across the plasma membrane: a clue to understanding drug-induced cytotoxicity. Curr. Drug Metab. 10: $347-358$

LOTFI K., MĹNSSONE., SPASOKOUKOTSKAJA T., PETTERSSON B., LILIEMARK J., PETERSON C., ERIKSSON S., ALBERTIONI F. 1999. Biochemical pharmacology and resistance to 2-chloro-2'-arabinofluoro-2'-deoxyadenosine, a novel analogue of cladribine in human leukemic cells. Clin. Cancer Res. 5: $2438-2444$

Mansson E., SpasokoukotSkaja T., SAllstrom J., ERIKSSON S., ALBERTIONI F. 1999. Molecular and biochemical mechanisms of fludarabine and cladribine resistance in a human promyelocytic cell line. Cancer Res. 59 5956-5963.

Marzo I., Perez-Galan P., Giraldo P., Rubio-Felix D., ANEL A., NAVAL J. 2001. Cladribine induces apoptosis in leukaemia cells by caspase-dependent and -independent pathways acting on mitochondria. Biochem. J. 359: 537-546.

NiITSU N., UMEDA M., HONMA Y. 2000. Myeloid and monocytoid leukemia cells have different sensitivity to differentiation-inducing activity of deoxyadenosine analogs. Leukemia Res. 24: 1-9.

PARKER W.B., SECRIST J.A. $3^{\text {rd }}$. WAUD W. R. 2004. Purine nucleoside antimetabolites in development for the treatment of cancer. Curr. Opin. Investig. Drug. 5: 592-596.

ROBAK T. 2003. Purine nucleoside analogues in the treatment of myeloid leukemias. Leukemia Lymphoma 44: 391-409.

ROBAK T., KORYCKA A., KASZNICKI M., WRZESIEŃ-KUS A., SOLEWSKI P. 2005. Purine nucleoside analogues for the treatment of hematological malignancies: pharmacology and clinical applications. Curr. Cancer Drug Targets 5: 421-444.

ROBAK T., KORYCKA A., ROBAK E. 2006a. Older and new formulations of cladribine. Pharmacology and clinical efficacy in hematological malignancies. Recent Pat. AntiCancer Drug Discov. 1: 23-38.

Robak T., LeCh-MARANDA E., Korycka A., Robak E. 2006b. Purine nucleoside analogs as immunosuppressive and antineoplastic agents: mechanism of action and clinical activity. Curr. Med. Chem. 13: 3165-3189.

ROBAK T., WiERZBOWSKA A., ROBAK E. 2006c. Recent clinical trials of cladribine in hematological malignancies and autoimmune disorders. Rev. Recent Clin. Trials. 1: 15-34.

StACHNIK K., GRIEB P., SKIERSKI J. S. 2005. Cytotoxic effects of cladribine and tezacitabine toward HL-60. Acta Biochim. Pol. 52: 561-565.

Wilson P.K., Szabados E., Mulligan S.P., ChristoPHERSON R.I. 1998. Comparative effects of cladribine, fudarabine and pentostatin on nucleotide metabolism in T- and B-cell lines. Int. J. Biochem. Cell Biol. 30: 833-842. 